$7^{\circ}$ Simposio Internacional de Investigación Multidisciplinaria / Ciencias de la Salud

7th Internationalm Symposium on Multidisciplinary Research / Health Sciences

\title{
CS-02 Coexistencia de desnutrición crónica con sobrepeso u obesidad en niños menores de cinco años en Guatemala
}

\section{Concurrent chronic malnutrition and overweight or obesity in children under age five in Guatemala}

\author{
Erwin H. Calgua-Guerra ${ }^{1}$, Cinthya C. Pinetta ${ }^{2}$ \\ ${ }^{1}$ Facultad de Ciencias Médicas, Universidad de San Carlos de Guatemala, y \\ ${ }^{2}$ Carrera de Nutrición, Universidad Rafael Landívar, Guatemala.
}

*Autor al que se dirige la correspondencia: drerwincalgua@gmial.com

\section{Resumen}

$\mathrm{E}$ n Guatemala la prevalencia de desnutrición crónica en niños es del 50\%, y se estima que uno de cada cuatro sufre de sobrepeso u obesidad. Este estudio pretende establecer la prevalencia de la coexistencia de desnutrición crónica, sobrepeso y obesidad en el mismo niño. Se hizo un estudio transversal en niños $<5$ años que participaron en la Encuesta Nacional de Salud Materno Infantil 2008/9. Los indicadores de talla y peso para edad, se usaron para evaluar su estado nutricional. El puntaje $\mathrm{z}<-2$ DE estableció desnutrición crónica; $\mathrm{z}>=1 \mathrm{y}<2$ DE, sobrepeso y $>=2$ DE, obesidad. Para el análisis descriptivo de datos se usó STATA/SE 14. De 10,325 niños, la desnutrición crónica, sobrepeso y obesidad se presentó en 49.2, 18.8 y $5.3 \%$ respectivamente. La coexistencia de desnutrición crónica con sobrepeso u obesidad en niños $<5$ años a nivel nacional fue de $10.6 \%$. La población indígena presentó una mayor prevalencia (13.9\%), afectó a 52.8\% de los niños, a $12 \%$ de los que habitan en el área rural. La coexistencia de desnutrición crónica con sobrepeso u obesidad en niños $<5$ años es una prioridad y problema de salud pública en Guatemala, especialmente en niños indígenas rurales. Es importante diseñar políticas, planes y programas de salud pública que tomen en cuenta la coexistencia de este problema nutricional en niños.

Palabras claves: Estado nutricional, niños indígenas

\begin{abstract}
$\mathrm{I}$ $\mathrm{n}$ Guatemala, the prevalence of stunting in children is $50 \%$, and it is estimated that 1 in 4 is overweight or obese. This study pretend to establish the prevalence of the coexistence of stunting, overweight and obesity in the same child. A cross-sectional study was carried out on children $<5$ years who participated in the 2008/9 National Maternal and Child Health Survey. Indicators of size and weight for age were used to assess their nutritional status. The score $<-2$ SD established stunting; $\mathrm{z}>=1$ and $<2$ SD, overweight, and $>=2 \mathrm{DE}$, obesity. STATA/SE 14 was used for descriptive data analysis. Of the 10,325 children, stunting, overweight and obesity presented in 49.2, 18.8 and $5.3 \%$, respectively. The coexistence of stunting with overweight or obesity in children $<5$ year at the national level was $10.6 \%$. Indigenous population had a higher prevalence $(13.9 \%)$, affected $52.8 \%$ of children, $12 \%$ of those living in rural areas. The coexistence of stunting with overweight or obesity in children under five is a priority and public health problem in Guatemala, especially in indigenous rural children. It is important to design public health policies, plans and programs that take into account the coexistence of this nutritional problem in children.
\end{abstract}

